\title{
ANALISIS PEMAKAMAN MULTI ETNIK DAN MULTI AGAMA DI KOTA METRO
}

\author{
Oleh: \\ Firmansyah \\ M. Dini Handoko \\ Institut Agama Islam Negeri Metro
}

\begin{abstract}
Abstrak
Penelitian ini menggunakan penelitian studi kasus, yaitu penelitian yang dilakukan pada data yang berwujud kasus-kasus. Lokasi yang dipilih adalah Kota Metro. Alasan keberatan mempersandingkan pemakaman jenazah antar agama yang seringkali membuat resah umat Islam adalah kepercayaan bahwa jenazah muslim akan ikut serta merasakan pedihnya siksaan Tuhan yang ditimpakan kepada non-muslim yang dimakamkan di sampingnya. Dari beberapa hadis yang telah dikumpulkan dapat diketahui bahwa tidak ditemukannya hadis yang melarang untuk memisahkan pemakamam umat yang berbeda agama. Dalam hal ini hanya terdapat keterangan bagaimana perlakuan sebuah jenazah, tata cara salat jenazah, cara Rasul membangun makam, dan juga beberapa kejadian tentang pemindahan jenazah yang telah disepakati para ulama, serta adab-adab untuk jiarah kubur bagi umat Islam. Islam dalam hal ini sangat menjunjung tinggi rasa toleransi beragama, bagaimana kita tidak hanya menghormati orang yang berbeda agama, akan tetapi juga menghormati jenazah yang berbeda agama.
\end{abstract}

Kata Kunci: Pemakaman Multi Etnik dan Multi Agama, Kota Metro

\begin{abstract}
This study is a case study that is research done on data tangible cases. The selected location is Lampung. The reason for the objection of matching the burial of inter-faith corpses that often clung to the minds of Muslims is the belief that Muslim bodies will share the pain of God's torment inflicted on non-Muslims buried beside him. From some of the hadis that have been collected it can be seen that the absence of hadiths forbids separation of people from different religions. In this case there is only information on the treatment of a corpse, the procedure of the corpses, the way the Apostle built the tomb, and also some incidents about the transfers of the bodies agreed upon by 'ulama, as well as the existence of the grave for the Muslims. In this case Islam strongly upholds the sense of religious tolerance, how we not only respect people of different religions, but also respect the bodies of different religions.
\end{abstract}

Keywords: Multi Ethnic Graveyard and Multi Religion, Metro City 


\section{A. PENDAHULUAN}

Pemakaman merupakan persemayaman terakhir dari suatu jasad bersemayam. Bisa saja itu merupakan tempat yang baik atau mungkin juga tempat yang akan membawa ke suatu hal yang kurang baik. Tetapi pemakaman dapat berubah menjadi satu masalah di masyarakat jika kita salah memahaminya. Salah satu persoalan besar yang mengganggu kerukunan umat beragama yang sudah lama berjalan dan dipupuk setiap saat adalah pemisahan tempat pemakaman mayat. Di beberapa daerah seringkali kita melihat gerbang makam bertuliskan TPU (Tempat Pemakaman Umum) ditambah nama daerahnya, di situ tersirat bahwa pemakaman tersebut dipakai atau digunakan oleh umum, semua kalangan bisa memakai. Ada juga gerbang pemakaman yang bertuliskan khusus bagi penggunanya, misalnya: Pemakaman Cina, yang di mana dikhususkan bagi orang-orang Cina atau Tionghoa. Di sinilah timbul pertannyaan apakah baik atau tidak jika pemakaman itu saling bersanding untuk setiap etnik dan agama.

Dalam dunia Islam pemakaman yang disesuaikan dengan agama jenazah memang mendapatkan justifikasi dari ahli hukum Islam masa lalu (fuqaha'). Dalam karya-karya fikihnya para fuqaha` mengklasifikasi non muslim menjadi dua; non muslim yang memusuhi umat Islam (kafir harbi) dan non muslim yang tunduk dan hidup berdampingan dengan umat Islam (kafir dzimmi). Konsep demikian sesungguhnya tidak memiliki landasan teologis, baik dari al-Quran, Hadis, maupun sejarah sahabat (atsar al-shahabah). Rumusan ini murni berdasarkan kondisi sosial masyarakat di mana para penulis kitab-kitab fikih itu hidup. Saat itu umat Islam di sebagian daerah sedang menghadapi serangan dari daerah luar yang kebetulan beragama lain, sehingga untuk membedakan mana kawan dan mana lawan para fuqaha membahasakannya dengan "muslim" dan "kafir", bagi kafir yang masih memusuhi umat Islam disebutnya dengan "kafir harbi".

Pemisahan umat agama lain dari masyarakat muslim ini tidak hanya dalam tataran istilah, melainkan juga dalam hak-haknya secara keseluruhan, termasuk di dalamnya persoalan pemakaman jenazah. Menurut fikih klasik non muslim dilarang dimakamkan di tempat yang berdampingan dengan makam umat Islam kecuali dalam keadaan terpaksa (dlarurah) seperti tidak ada tempat lain yang layak digunakan untuk pemakaman. Non muslim dimaksud adalah kafir dzimmi, sedangkan bagi kafir harbi haram dimakamkan, tapi harus dibuang jauh-jauh, disingkirkan dari daerah yang dikuasai umat Islam. ${ }^{1}$

\footnotetext{
${ }^{1}$ Syihabuddin Al-Ramli, vol. III, hal. 8, 1984
} 
Rumusan fikih demikian yang sangat terlihat kurang bijak terhadap non muslim. Nabi Muhammad Saw tidak pernah mengajarkan kekerasan dalam hal bermasyarakat. Nabi Muhammad Saw. dan sahabatnya dalam memperlakukan umat agama lain yang memusuhinya tidak dengan cara-cara yang kejam hingga dapat merusak martabat kemanusiaan. Nabi Saw. hanya memperbolehkan memerangi musuh di medan peperangan. Ketika musuh menyerah maka tidak boleh dibunuh. Dalam membunuh musuh dilarang dengan menggunakan cara yang tidak manusiawi seperti dengan memotong anggota tubuh musuh yang sudah mati, menyalib, dan yang lainnya walaupun musuh melakukan tindakan seperti itu. Ketika hendak berperang nabi Muhammad Saw. membaca doa: "Allahumma inna 'ibaduka wa hum 'ibaduk, nawashina wa nawashihim biyadik, Allahumma ihzamhum wan shurna 'alaihim (Ya Allah, sesungguhnya kami adalah hamba-Mu, mereka juga hamba-Mu, kemenangan kami dan kemenangan mereka ada dalam kekuasaan-Mu. Ya Allah kalahkanlah mereka, tolonglah kami untuk mengalahkan mereka)." Dalam do'a tersebut nabi Muhammad Saw. menyebutkan musuh-musuhnya dengan ungkapan "mereka juga hamba-Mu", penyebutan hamba Allah seperti dirinya sendiri dan umat Islam lainnya, merupakan salah satu sikap Nabi Saw. yang tidak pernah merendahkan manusia, baik manusia yang memusuhinya maupun tidak. Di sini terlihat betapa indahnya akhlak kaum muslimin yang tergambar dalam diri Nabi Muhammad Saw.

Rumusan fikih klasik yang melarang pemakaman jenazah non muslim di makam umat Islam di atas selain sudah tidak memiliki relevansi dengan kondisi kekinian, juga bertentangan dengan ajaran Islam itu sendiri yang memerintahkan umat Islam untuk menghormati kepada semua umat manusia (QS. 17:70).

Penghormatan terhadap sesama manusia yang diperintahkan al-Quran meniscayakan kemutlakan, yakni melampaui sekat agama, ras, suku, dan budaya, karena dalam Islam semua manusia dengan beragam jenis kelaminnya, agama, ras, suku, dan budayanya diyakini berasal dari satu sumber (min nafs wahidah) yang diciptakan Allah (QS. 4:1).

Alasan keberatan mempersandingkan pemakaman jenazah antar agama yang seringkali menggelayuti benak umat Islam adalah kepercayaan bahwa jenazah muslim akan ikut serta merasakan pedihnya siksaan Tuhan yang ditimpakan kepada non muslim yang dimakamkan di sampingnya. Apabila dikaji lebih lanjut sesungguhnya alasan ini tidak berdasar, karena dalam al-Quran maupun Hadis dinyatakan bahwa balasan amal perbuatan manusia di dunia hanya akan dilaksanakan kelak di akhirat, bukan di dunia. Dalam Islam 
kuburan hanyalah tempat penampungan jasad mati, sementara ruhnya diyakini kembali ke hadapan Allah (inna lillahi wa inna ilaihi raji'un). Darlam tulisan ini akan coba diungkap permasalahan pemakaman multi etnik dan multi agama yang ada di Kota Metro.

\section{B. PEMBAHASAN}

\section{Pemakaman/ Kuburan}

Kita perhatikan di banyak daerah sebagian kuburan dicor dengan semen seukuran panjang $1 \mathrm{~m}$ dan lebar $1 / 2 \mathrm{~m}$, dan dituliskan padanya nama jenazah, tanggal wafatnya, dan sebagian kalimat seperti: "Ya Allah berilah rahmat kepada Fulan bin Fulan...”.

Pada tulisan ini akan coba diulas tentang hal tersebut. Tidak boleh membangun pada kubur, baik dengan cor ataupun yang lain, demikian pula menulisinya. Karena terdapat riwayat yang shahih dari Nabi Shallallahu 'alaihi wa sallam tentang larangan membangun di atas kuburan dan menulisinya. Al-Imam Muslim telah meriwayatkan dari hadits Jabir radhiyallahu 'anhu, ia berkata:

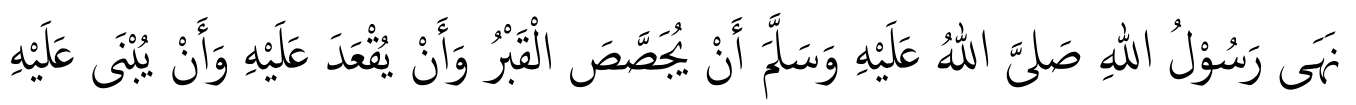

"Rasulullah Shallallahu 'alaihi wa sallam melarang kuburan dikapur, diduduki, dan dibangun."

Al-Imam At-Tirmidzi dan yang lain meriwayatkan dengan sanad yang shahih dengan tambahan lafadz:

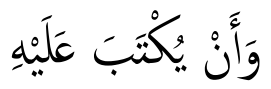

\section{"dan ditulisi."}

Karena hal itu termasuk salah satu bentuk sikap berlebihan sehingga harus dilarang. Juga karena penulisan bisa menghantarkan kepada dampak yang parah berupa sikap berlebihan dan larangan-larangan syar'i lainnya. Yang diperbolehkan hanyalah mengembalikan tanah (galian) kubur tersebut dan ditinggikan sekitar satu jengkal sehingga diketahui bahwa itu adalah kuburan. Inilah yang sunnah dalam masalah kuburan dan ini yang dilakukan oleh Rasulullah serta para sahabatnya radhiyallahu 'anhum.

Tidak boleh pula menjadikan kuburan sebagai masjid (yaitu tempat untuk shalat atau shalat menghadapnya). Tidak boleh pula mengerudunginya atau membuat kubah di atasnya, berdasarkan sabda Nabi Shallallahu 'alaihi wa sallam: 


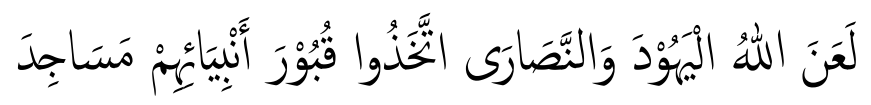

"Allah melaknat Yahudi dan Nasrani karena mereka menjadikan kubur nabi-nabi mereka sebagai tempat ibadah.” (Muttafaqun 'alaih)

Juga berdasarkan hadits yang diriwayatkan Al-Imam Muslim dalam Shahih-nya dari sahabat Jundub bin Abdillah Al-Bajali radhiyallahu 'anhu, dia berkata:

Aku mendengar Rasulullah Shallallahu 'alaihi wa sallam bersabda lima hari sebelum meninggalnya:

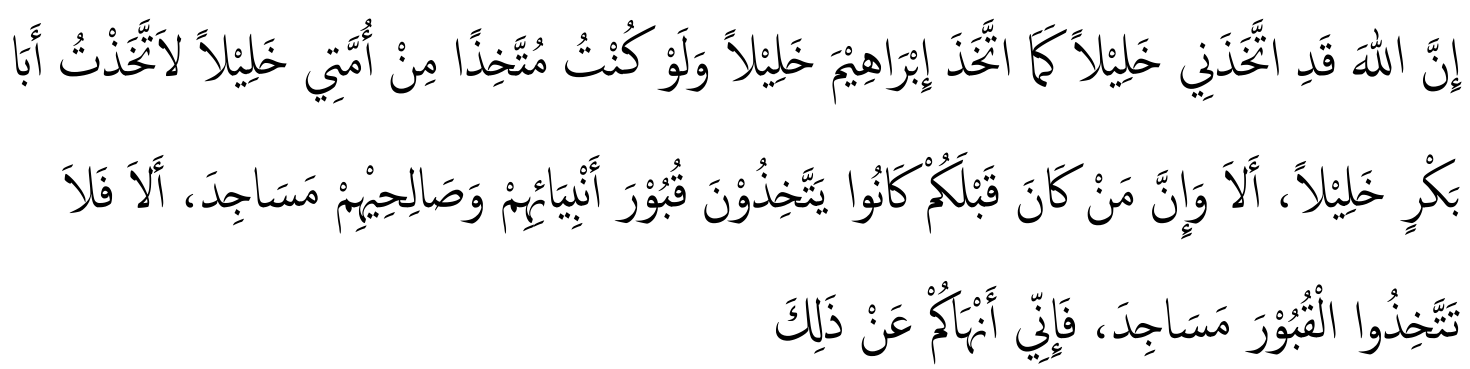

"Sesungguhnya Allah telah menjadikan aku sebagai kekasih-Nya sebagaimana menjadikan Ibrahim sebagai kekasih-Nya. Seandainya aku mau menjadikan seseorang dari umatku sebagai kekasihku tentu aku akan menjadikan Abu Bakar sebagai kekasihku. Ketahuilah bahwa orang-orang sebelum kalian telah menjadikan kubur nabi-nabi dan orang shalih mereka sebagai tempat ibadah. Ketahuilah, janganlah kalian menjadikan kubur-kubur sebagai masjid karena sesungguhnya aku melarang kalian dari perbuatan itu."

Dan hadits-hadits yang semakna dengan ini banyak. Aku memohon kepada Allah Subhanahu wa Ta'ala agar memberikan taufiq-Nya kepada muslimin agar berpegang teguh dengan Sunnah Nabi mereka dan tegar di atasnya, serta berhati-hati dari segala yang menyelisihinya. Sesungguhnya Dia Maha Mendengar dan Maha Dekat. ${ }^{2}$

Dari Abu Al-Hayyaj Al-Asadi dia berkata: Ali bin Abu Thalib berkata kepadaku:

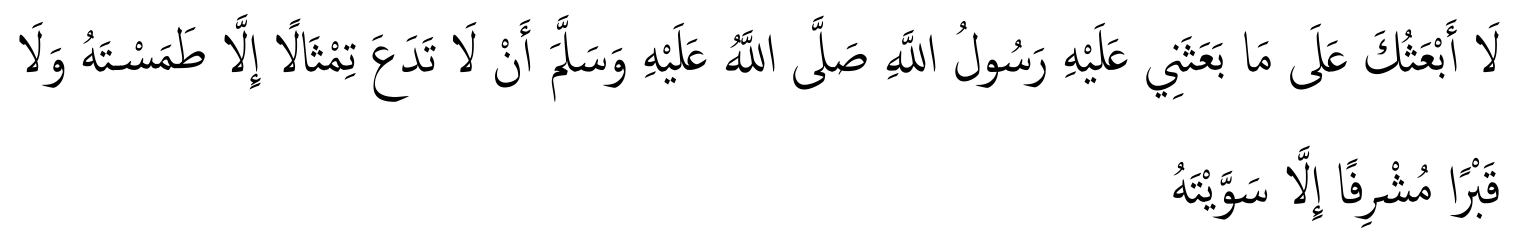

${ }^{2}$ Mukhtarat min Kitab Majmu' Fatawa Wa Maqalat Mutanawwi'ah, hal. 228-229 
"Maukah kamu aku utus sebagaimana Rasulullah shallallahu 'alaihi wasallam telah mengutusku? Hendaklah kamu jangan meninggalkan gambar-gambar kecuali kamu hapus dan jangan pula kamu meninggalkan kuburan kecuali kamu ratakan. „3

Fadhalah bin Ubaid radhiallahu 'anhu berkata:

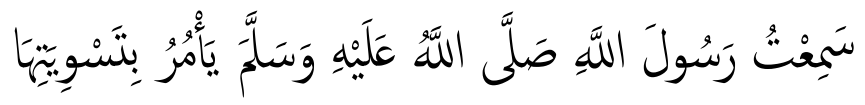

"Saya telah mendengar Rasulullah shallallahu 'alaihi wasallam memerintahkan untuk meratakannya (kuburan), ,4

Dari Jabir bin Abdillah radhiallahu 'anhuma dia berkata:

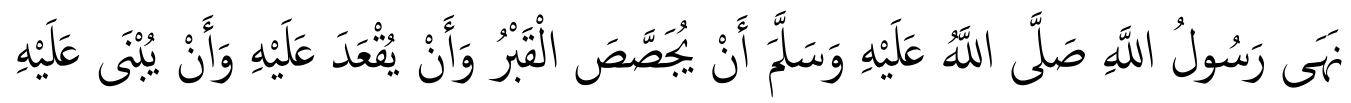

"Rasulullah shallallahu 'alaihi wasallam melarang mengapur kuburan, duduk di atasnya, dan membuat bangunan di atasnya, ,5

Al-Imam At-Tirmidzi dan yang lain meriwayatkan dengan sanad yang shahih dengan tambahan lafadz:

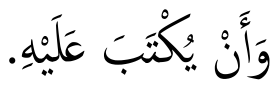

Al-Imam Asy-Syaukani rahimahullahu menerangkan: "Ketahuilah bahwa kaum Muslimin yang dahulu dan akan datang, yang awal dan akhir, sejak zaman sahabat sampai waktu kita ini, telah bersepakat bahwa meninggikan kuburan dan membangun di atasnya termasuk perkara bid'ah, yang telah ada larangan dan ancaman keras dari Rasulullah Shallallahu 'alaihi wa sallam atas para pelakunya."

Al-Imam Asy-Syafi'i rahimahullahu berkata: “Aku menginginkan kuburan itu tidak dibangun dan tidak dikapur (dicat), karena perbuatan seperti itu menyerupai hiasan atau kesombongan, sedangkan kematian bukanlah tempat salah satu di antara dua hal tersebut. Aku tidak pernah melihat kuburan Muhajirin dan Anshar dicat. Perawi dari Thawus berkata:

\footnotetext{
${ }^{3}$ HR Muslim No. 969

${ }^{4}$ HR Muslim No. 968

${ }^{5}$ HR Muslim No. 970
} 
'Nabi Shallallahu 'alaihi wa sallam melarang kuburan dibangun atau dicat'." Beliau rahimahullahu juga berkata: "Aku membenci dibangunnya masjid di atas kuburan."

Al-Imam Asy-Syafi'i rahimahullahu berkata pula: "Aku membenci ini berdasarkan Sunnah Rasulullah Shallallahu 'alaihi wa sallam dan atsar..."

Asy-Syaikh Sulaiman Alu Syaikh rahimahullahu berkata: "Al-Imam Nawawi rahimahullahu menegaskan dalam Syarh Al-Muhadzdzab akan haramnya membangun kuburan secara mutlak. Juga beliau sebutkan semisalnya dalam Syarh Shahih Muslim.”

Dari Jabir radhiallahu 'anhu: "Bahwa telah dibuatkan untuk beliau (Nabi shallallahu 'alaihi wasallam) liang lahat dan diletakkan di atasnya batu serta ditinggikannya di atas tanah sekitar satu jengkal,",6

Dari Sufyan at Tamar, dia berkata: "Aku melihat makam Nabi shallallahu 'alaihi wasallam dibuat gundukkan seperti punuk,"7

Ibnul Qayyim berkata dalam kitabnya Zaadul Ma'aad, "Dan makam beliau shallallahu 'alaihi wa sallam digunduki tanah seperti punuk yang berada di tanah lapang merah. Tidak ada bangunan dan tidak juga diplester. Demikian itu pula makam kedua sahabatnya (Abu Bakar dan Umar).”

Hal tersebut menunjukkan bahwa kuburan Nabi tidaklah dibangun seperti bangunan sekarang ini pada awalnya. Jadi dibangunnya kuburan Nabi bukanlah hujjah yang dapat dipakai, kecuali jika yang membangunnya tersebut adalah para sahabat Nabi dan atas ijma (kesepakatan) mereka.

Pada tahun 88 Hijriah, Al Walid bin Abdul Malik merehab masjid Nabi dan memperluas masjid hingga ke kamar 'Aisyah. Berarti kuburan beliau masuk ke dalam area masjid. Sementara pada saat itu sudah tidak ada satu sahabat pun yang masih hidup, sehingga dapat menentang tindakan Al Walid ini seperti yang diragukan oleh sebagian manusia.

Al Hafizh Muhamad Abdul-Hady menjelaskan di dalam bukunya Ash-Sharimul Manky: "Bilik (kamar) Rasulullah masuk dalam masjid pada zaman Al Walid bin Abdul Malik, setelah semua sahabat beliau di Madinah meninggal. Sahabat terakhir yang meninggal adalah Jabir bin Abdullah. Ia meninggal pada zaman Abdul Malik pada tahun 78 Hijriah. Sementara Al Walid menjadi khalifah pada tahun 86 Hijriah, dan meninggal pada tahun 96

\footnotetext{
${ }^{6}$ HR Ibnu Hibban dalam kitab Shahihnya No. 2160 dan al Baihaqi III/410, hadits ini sanadnya hasan

7 HR Bukhari III/198-199 dan Baihaqi IV/3
} 
Hijriah. Rehabilitasi masjid dan memasukkan bilik beliau ke dalam masjid, dilakukan antara tahun-tahun itu.

Abu Zaid Umar bin Syabbah An Numairy berkata di dalam bukunya AkhbarulMadinah: "Ketika Umar bin Abdul Aziz menjadi gubernur Madinah pada tahun 91 Hijriah, ia merobohkan masjid lalu membangunnya lagi dengan menggunakan batu-batu yang diukir, atapnya terbuat dari jenis kayu yang bagus. Bilik istri-istri Nabi shallallahu 'alaihi wasallam dirobohkan pula lalu dimasukkan ke dalam masjid. Berarti kuburan beliau juga masuk ke dalam masjid."

Dari penjelasan ini jelaslah sudah bahwa kuburan beliau masuk menjadi bagian dari Masjid Nabawi, ketika di Madinah sudah tidak ada seorang sahabat pun. Hal ini ternyata berlainan dengan tujuan saat mereka menguburkan jasad Rasulullah di dalam biliknya. Maka setiap Muslim yang mengetahui hakikat ini, tidak boleh berhujjah dengan sesuatu yang terjadi sesudah meninggalnya para sahabat. Sebab hal ini bertentangan dengan hadits-hadits shahih dan pengertian yang diserap para sahabat serta pendapat para imam.

Hal ini juga bertentangan dengan apa yang dilakukan Umar dan Utsman ketika memperluas Masjid Nabawi tersebut. Mereka berdua tidak memasukkan kuburan beliau ke dalam masjid. Maka dapat kita putuskan, perbuatan Al Walid adalah salah. Kalaupun terdesak untuk meluaskan Masjid Nabawi, beliau bisa meluaskan dari sisi lain sehingga tidak mengusik kuburan beliau. Umar bin Khaththab pernah mengisyaratkan segi kesalahan semacam ini. Ketika memperluas masjid, ia mengadakan perluasan di sisi lain dan tidak mengusik kuburan beliau. Ia berkata: "Tidak ada alasan untuk berbuat seperti itu." Umar memberi peringatan agar tidak merobohkan masjid, dan juga tidak memasukkan kuburan beliau ke dalam masjid.

Karena tidak ingin bertentangan dengan hadits dan kebiasaan khulafa'urrasyidin, maka orang-orang Islam sesudah itu sangat berhati-hati dalam meluaskan Masjid Nabawi. Mereka mengurangi kontroversi sebisa mungkin. Dalam hal ini An-Nawawi menjelaskan di dalam Syarh Muslim: "Ketika para sahabat yang masih hidup dan tabi' in merasa perlu untuk meluaskan Masjid Nabawi karena banyaknya jumlah kaum Muslimin, maka perluasan masjid itu mencapai rumah Ummahatul-Mukminin, termasuk bilik 'Aisyah, tempat dikuburkannya Rasulullah dan juga kuburan dua sahabat beliau, Abubakar dan Umar.

Mereka membuat dinding pemisah yang tinggi di sekeliling kuburan, bentuknya melingkar, sehingga kuburan tidak langsung nampak sebagai bagian dari masjid. Dan orangorangpun tidak shalat ke arah kuburan itu, sehingga merekapun tidak terseret pada hal-hal yang dilarang. 
Ibnu Taimiyah dan Ibnu Rajab yang menukil dari 1-Qurthuby, menjelaskan: "Ketika bilik beliau masuk ke dalam masjid, maka pintunya di kunci, lalu disekelilingnya dibangun pagar tembok yang tinggi. Hal ini dimaksudkan untuk menjaga agar rumah beliau tidak dipergunakan untuk acara-acara peringatan dan kuburan beliau dijadikan patung sesembahan."

Dapat dikatakan: memang sangat disayangkan bangunan tersebut sudah didirikan sejak berabad-abad di atas kuburan Nabi shallallahu 'alaihi wasallam. Di sana ada kubah menjulang tinggi berwarna hijau, kuburan beliau dikelilingi jendela-jendela yang terbuat dari bahan tembaga, berbagai hiasan dan tabir. Padahal semua itu tidak diridhai oleh orang yang dikuburkan di situ, yaitu Rasulullah shallallahu 'alaihi wasallam. Bahkan ketika berkunjung ke sana, di samping tembok sebelah utara terdapat mihrab kecil. Ini merupakan isyarat bahwa tempat itu dikhususkan untuk shalat di belakang kuburan. Bagaimana bisa terjadi paganisme yang sangat mencolok ini dibiarkan begitu saja oleh suatu negara yang, katanya, "mengagung-agungkan tauhid".

Tetapi ini belum cukup dan tidak memberikan jalan keluar yang tuntas. Tentang hal ini sudah lama kami katakan di dalam buku Ahkamul Jana' iz wa Bida'uha: "Seharusnya Masjid Nabawi dikembalikan ke zamannya semula, yaitu dengan membuat tabir pemisah antara kuburan dengan masjid, berupa tembok yang membentang dari utara ke selatan, sehingga setiap orang yang masuk ke masjid tidak dikejar oleh macam-macam pertentangan yang tidak diridhai pendirinya.

Kami merasa yakin, ini merupakan kewajiban pemerintah Saudi, kalau masih ingin menjaga akidah dan tauhid yang benar. Andai ada rencana perluasan kembali, maka bisa melebar kesebelah barat atau sisi lainnya. Tapi ketika diadakan perbaikan lagi, ternyata Masjid Nabawi tidak dikembalikan ke bentuknya yang pertama sesuai pada zaman sahabat."

\section{Ziarah Kubur}

\section{- Tatacara dan Adab Ziarah Kubur:}

Tujuan utama ziarah kubur adalah mengingat mati dan mengingat akhirat sebagaimana dinyatakan Rasulullah Shallallahu 'Alaihi wa Sallam, "Aku pernah melarang kalian untuk berziarah kubur, maka ziarahilah (sekarang)! Karena sesungguhnya ziarah kubur dapat mengingatkan kalian akan kematian.” (HR Muslim dari Abu Buraidah)

\footnotetext{
8 Syeikh Muhammad Nashiruddin Al-Albani, "Peringatan! Menggunakan Kuburan Sebagai Masjid", Bab IV/ h.50 - 83
} 
Dari Anas bin Malik, "Sesungguhnya ziarah itu akan melunakkan hati, mengundang air mata dan mengingatkan pada hari kiamat." (HR Al Hakim)

Oleh karena itu, tujuan itu harus senantiasa dipancangkan di dalam hati orang yang berziarah. Selain itu, ada beberapa adab dalam berziarah kubur:

1) Dianjurkan Melepas Alas Kaki

Dianjurkan menurut madzhab Hanbali, melepas sandal ketika masuk ke areal pemakaman karena ini sesuai dengan perintah dalam hadits Busyair bin Al Khashahshah:

Ketika aku berjalan mengiringi Rasulullah Shallallahu 'Alaihi wa Sallam, ternyata ada seseorang berjalan di kuburan dengan mengenakan kedua sandalnya. Maka Nabi Shallallahu "Alaihi wa Sallam mengatakan "Hai pemakai dua sandal, tanggalkan kedua sandal kamu!" Orang itu pun menoleh. Ketika dia tahu bahwa itu ternyata Rasulullah Shallallahu 'Alaihi wa Sallam, ia melepaskannya serta melemparkan keduanya. ${ }^{9}$

Diperbolehkan tetap memakai sandal jika ada penghalang semacam duri, kerikil yang panas, atau semacam keduanya. Ketika itu, tidak mengapa berjalan dengan kedua sandal di antara kuburan untuk menghindari gangguan itu.

2) Mengucapkan Salam

Disunnahkan bagi orang yang berziarah mengucapkan salam kepada penghuni kuburan Muslim. Adapan ucapan salam hendaklah menghadap wajah mayat, lalu mengucapkan salam sebagaimana telah diajarkan oleh Nabi Shallallahu 'Alaihi wa Sallam kepada para Shahabatnya ketika mereka berziarah kubur,

“Assalamu 'alaikum dara qaumin Mu'minin, wa insya Allah bikum laa hiqun."

Artinya, "Keselamatan atas kalian di tempat orang Mukmin, dan kami insya Allah akan menyusul kalian juga."

Atau bisa juga dengan lafal lain, “Assalamu 'ala ahlid diyari minal Mu'minina wal Muslimin, wa inna insya Allah ta'ala bikum laa hiqun. As-alullahu lana wa lakumul afiyah."

Artinya, "Keselamatan kepada penghuni kubur dari kaum Mukminin dan Muslimin, kami insya Allah akan menyusul kalian. Aku memohon keselamatan kepada Allah untuk kami dan kalian semua."

Kedua lafazh salam tersebut diriwayatkan Imam Muslim.

\footnotetext{
9 HR. Abu Dawud, hasan
} 
3) Membaca Surat Pendek

Dianjurkan membacakan Al Quran atau surat pendek. Ini adalah sunnah yang dilakukan di kuburan. Pahalanya untuk orang yang hadir, sedang mayat seperti halnya orang yang hadir yang diharapkan mendapatkan rahmat.

Disunnahkan membaca surat Yasin seperti yang diriwayatkan Ahmad, Abu Dawud, Ibnu Hibban, dan Al Hakim dari Ma'qal bin Yassar, Rasulullah Shallallahu 'Alaihi wa Sallam bersabda, "Bacakanlah surah Yasin pada orang yang meninggal di antara kalian."

Sebagian ulama menyatakan hadits ini dha'if. Imam Asy Syaukani dan Syaikh Wahbah Az Zuhaili menyebutkan bahwa hadits ini berstatus hasan. Ibnu Taimiyah mengatakan bahwa membacakan Al Quran ini dilakukan saat sakaratul maut, bukan setelah meninggal.

4) Mendoakan si Jenazah

Selanjutnya mendoakan untuk mayat usai membaca Al Quran dengan harapan dapat dikabulkan. Sebab doa sangat bermanfaat untuk mayat. Ketika berdoa, hendaknya menghadap kiblat.

Saat berziarah kubur di Baqi', Rasulullah Shallallahu 'Alaihi wa Sallam berdoa dengan lafazh, "Allahummaghfir li Ahli Baqi'il gharqad."

5) Berziarah dalam Posisi Berdiri

Disunnahkan ketika berziarah dalam keadaan berdiri dan berdoa dengan berdiri, sebagaimana yang dilakukan Rasulullah Shallallahu 'Alaihi wa Sallam ketika keluar menuju Baqi'.

Selain itu, jangan duduk dan berjalan di atas pusara kuburan. Dalam riwayat Muslim, Rasulullah Shallallahu 'Alaihi wa Sallam bersabda, "Sungguh jika salah seorang dari kalian duduk di atas bara api sehingga membakar bajunya dan menembus kulitnya, itu lebih baik daripada duduk di atas kubur." Sedangkan jika berjalan di samping atau di antara pusara-pusara kubur, maka itu tidak mengapa.

6) Menyiramkan Air di Atas Pusara

Diperbolehkan menyiramkan air biasa di atas pusara si mayat berdasarkan hadits berikut, "Sesungguhnya Nabi Muhammad Shallallahu "Alaihi wa Sallam menyiram (air) di atas kubur Ibrahim, anaknya, dan meletakkan kerikil di atasnya." Hadits diatas oleh Abu Dawud dalam Al Marasil, Imam Baihaqi dalam Sunan, Thabarani dalam Mu'jam Al Ausath. Syaikh Al Albani menyatakan sanadnya kuat di dalam Silsilah Ahadits Shahihah. 
Sedangkan menyiram dengan air kembang tujuh rupa atau menabur bunga, maka itu tidak dituntunkan oleh syari'at.

Hal-hal yang Makruh dan Munkar Saat Berziarah. Madzhab Maliki menyatakan makruh hukumnya makan, minum, tertawa, dan banyak bicara, termasuk juga membaca $\mathrm{Al}$ Quran dengan suara keras. Tidaklah pantas bagi seseorang yang berada di pemakaman, baik dia bermaksud berziarah atau hanya secara kebetulan untuk berada dalam keadaan bergembira dan senang seakan-akan dia berada pada suatu pesta, seharusnya dia ikut hanyut atau memperlihatkan perasaan ikut hanyut di hadapan keluarga mayat.

Syaikh Wahbah Az Zuhaili menyebutkan, "Makruh hukumnya mencium peti yang dibuat di atas makam, atau mencium makam, serta menyalaminya, atau mencium pintunya ketika masuk berziarah makam aulia."

Mengkhususkan hari-hari tertentu dalam melakukan ziarah kubur, seperti harus pada hari Jum'at, tujuh atau empat puluh hari setelah kematian, pada hari raya dan sebagainya, maka itu tak pernah diajarkan oleh Rasulullah dan beliau pun tidak pernah mengkhususkan hari-hari tertentu untuk berziarah kubur. Sedangkan hadits-hadits tentang keutamaan ziarah pada hari Jum'at adalah dha'if sebagaimana dinyatakan para Imam Muhaditsin. Oleh karena itu, ziarah kubur dapat dilakukan kapan saja.

Sedangkan shalat persis di atas kuburan seseorang dan menghadap kuburan tanpa tembok penghalang, maka ulama sepakat tentang ketidakbolehannya. Rasulullah Shallallahu 'Alaihi wa Sallam bersabda, "Janganlah kalian shalat menghadap kuburan dan jangan pula kalian duduk di atasnya." (HR Muslim)

Sedangkan jika di samping kubur, maka terjadi sejumlah perselisihan ulama, ada yang memakruhkannya, dan ada yang mengharamkannya. Demi kehati-hatian, kami berpendapat untuk tidak melaksanakan shalat di kompleks pekuburan. Selain itu, Ibnu Hibban meriwayatkan dari Anas bin Malik, Rasulullah Shallallahu 'Alaihi wa Sallam melarang dari shalat di antara kuburan." Dikecualikan dari hal ini adalah bagi seseorang yang ingin melaksanakan shalat jenazah, tetapi tidak berkesempatan menshalati mayit saat belum dikuburkan.

Dilarang juga mengencingi dan berak di atas kuburan. Diriwayatkan Abu Hurairah, bersabda Rasulullah Shallallahu 'Alaihi wa Sallam, "Barang siapa yg duduk di atas kuburan, yang berak dan kencing di atasnya, maka seakan dia telah menduduki bara api.”

Tidak diperbolehkan melakukan thawaf (ibadah dengan cara mengelilingi) kuburan. Hal ini sering dijumpai dilakukan oleh orang-orang awam di kuburan orang-orang shalih. 
Dan ini termasuk dalam kesyirikan. Thawaf hanya boleh dilakukan pada Baitullah Ka'bah. Allah berfirman, "Dan hendaklah mereka melakukan Thawaf disekeliling rumah yang tua (Baitul 'Atiq atau Baitullah) itu."10

Berdoa, meminta perlindungan, meminta tolong, pada penghuni kubur juga tidak diperbolehkan, hukumnya haram dan merupakan kesyirikan. Berdoa hanya boleh ditujukan pada Allah Subhanahu wa Ta'ala. Sedangkan berdoa dengan perantaraan si mayit (tawasul), maka hal itu diperselisihkan. Pendapat yang kuat adalah tidak diperbolehkan.

Tidak diperbolehkan memasang lilin atau lampu di atas pusara kuburan. Selain hal itu merupakan tatacara ziarah orang Ahli Kitab dan Majusi, dalam riwayat Imam Al Hakim disebutkan, "Rasulullah melaknat....dan (orang-orang yang) memberi penerangan (lampu pada kubur)."

Tidak boleh memberikan sesajen berbentuk apapun, baik berupa bunga, uang, masakan, beras, kemenyan, dan sebagainya. Juga dilarang menyembelih hewa atau kurban di kuburan. Selain itu, tidak boleh mengambil benda-benda dari kubur seperti kerikil, batu, tanah, bunga, papan, pelepah, tulang, tali dan kain kafan, serta yang lainnya untuk dijadikan jimat.

\section{Pemindahan Jenazah}

Mengenai pemindahan makam Majelis Ulama Indonesia pernah menfatwakan ketika akan memindahkan jenazah almarhum bung Tomo dari tanah Suci ke tanah air. Yang isinya sebagai berikut:

Pada bulan Oktober 1981, Majelis Ulama Indonesia menerima surat dari Bambang Sulastomo perihal pemindahan jenazah almarhum bung Tomo dari tanah Suci ke tanah air. Setelah rapat Komisi Fatwa pada tanggal 13 oktober 1981, Majelis Ulama Indonesia memberikan penjelasan kepada Bambang Sulastomo sebagai berikut:

1. Mengenai lazimnya para jama'ah haji yang meninggal di tanah suci itu dimakamkan di sana sebagai suatu kehormatan dan rahmat Allah yang tinggi, maka kami berpendapat bahwa lebih baik jenazah almarhum yang dimakamkan di sana tidak dipindahkan.

2. Jika sekiranya memang ada pertimbangan lain, yang mendorong untuk memindahkan juga, maka perlu diketahui sebagian besar para Ulama, menetapkan bahwa memindahkan jenazah yang telah dimakamkan itu tidak boleh, kecuali ada alasan yang dibenarkan oleh syari'at. Adapun Imam Maliki membolehkan pemindahan jenazah yang telah dimakamkan dengan alasan kemaslahatan, di antaranya untuk memudahkan

${ }^{10}$ QS Al Hajj : 29 
ziarah atau dimakamkan di tengah makam keluarga

3. Jika sekiranya alternatif kedua yang akan ditempuh, perlu kiranya dimintakan petunjuk-petunjuk kepada pemerintah

4. Kiranya patut pula menjadi pertimbangan biaya yang tentunya besar itu, akan dapat lebih dimanfaatkan untuk beramal jariyah yang akan besar manfaatnya bagi almarhum. $^{11}$

Dari fatwa tersebut dapat diketahui bahwa pemindahan jenazah ada beberapa syarat tertentu yang harus dipenuhi. Pada lain pembahasan ada beberapa pendapat mengenai pemindahan jenazah. Hadist Nabi mengatakan:

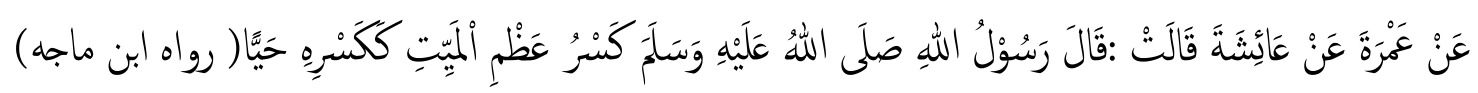

Dari Amrah dari 'Aisyah ia berkata, Rasulullah SAW bersabda: Memecahkan (merusak) tulang seorang yang telah meninggal sama seperti memecahkannya (merusak) ketika masih hidup. $^{12}$

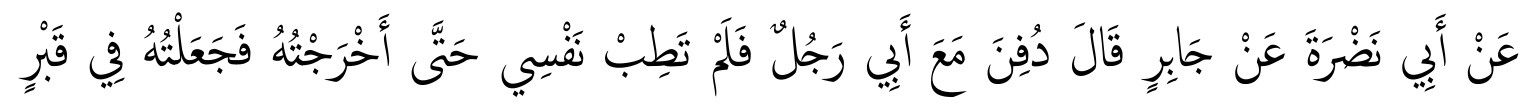

$$
\begin{aligned}
& \text { عَلَى حِدَةٍٍ ( رواه البخاري) }
\end{aligned}
$$

Dari Abu Nadhrah, dari Jabir ia berkata, seorang laki-laki dikuburkan bersama dengan bapakku, namun perasaanku tidak enak, hingga akhirnya aku keluarkan beliau dari kuburan dan aku kuburkan beliau dalam satu liang kubur sendiri. ${ }^{13}$

Dari beberapa pendapat Ulama, ada yang menyatakan bahwa:

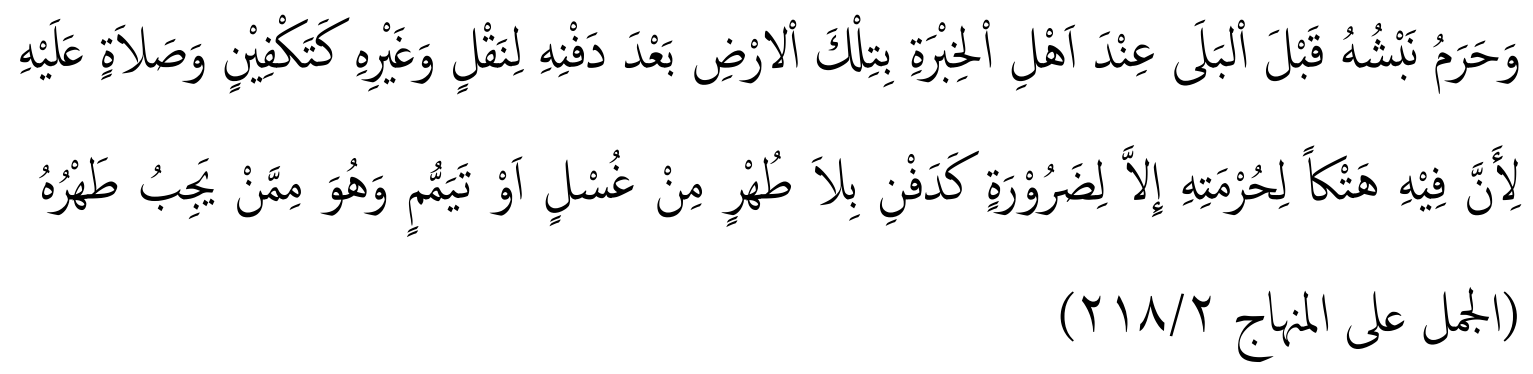

\footnotetext{
${ }^{11}$ K.H. Ma'ruf Amin, dkk. 2011. HIMPUNAN FATWA MAJELIS ULAMA INDONESIA SEJAK 1975, Jakarta: Erlangga. h. 305

12 HR. Ibn Majah

${ }^{13}$ HR. Al-Bukhori
} 
Haram membongkar kembali mayat setelah dikuburkan sebelum mayat tersebut diyakini sudah hancur sesuai dengan pendapat para pakar tentang tanahnya, untuk dipindahkan ataupun yang lainnya, seperti mengkafani dan mensholati, karena dapat merusak kehormatan mayat kecuali darurat, seperti dikuburkan tanpa disucikan, baik dimandikan ataupun tayamum, sedangkan mayat tersebut merupakan orang yang harus disucikan. ${ }^{14}$

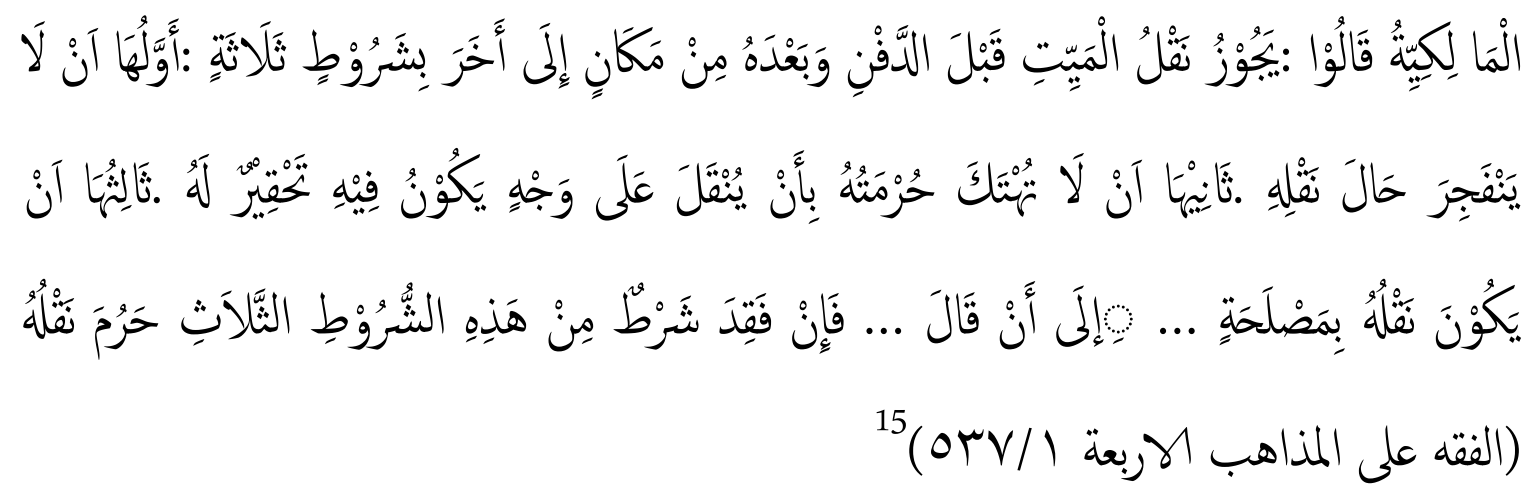

Ulama Maliki berpendapat boleh memindahkan mayat sebelum dan sesudah dikubur dari suatu tempat ke tempat yang lain dengan tiga syarat:

1) Mayat tidak pecah (rusak) ketika dipindah

2) Tidak sampai menodai kehormatannya, misalnya memindahkan dengan cara yang dapat menghinakannya

3) Kepindahan itu karena ada sesuatu kepentingan

Jika satu syarat dari ketiga syarat ini tidak terpenuhi, maka haram memindahkannya. ${ }^{16}$

Memindahkan kuburan atau makam dalam bahasa arab sering di sebutkan dalam istilah:

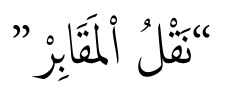

yaitu suatu upaya memindahkan perkuburan dari suatu lokasi kepada lokasi yang lain karena perkuburan yang lama tidak dapat lagi berfungsi sebagaimana biasanya, atau ada pertimbangan-pertimbangan lain yang mendesaknya. ${ }^{17}$

\footnotetext{
14 Sahal Mahfudh, Ahkamul Fuqaha, Solusi Problematika Aktual Hukum islam (Surabaya: LTN NU Jawa Timur, 2004), h.501

${ }^{15}$ Abdurrahman Al-Jaziri, al-Fiqh ‘alal Madzahibil Arba 'ah, Juz I, (Beirut: Dar al-Kuitub al-Alawiyah, t.th), h. 537

${ }^{16}$ Al-Fiqh ‘alal Madzahibil Arba'ah 1/537

17 Mahjudin, Masailul Fiqhiyah, Berbagai Kasus yang Dihadapi Islam Masa Kini jilid I, (Jakarta: Kalam Mulia, 1990), h. 147
} 
Para Ulama telah sepakat bahwa asalnya membongkar kuburan untuk dipindahkan atau tujuan lainnya yang tidak ada kepentingan darinya adalah perbuatan yang dilarang dalam Islam, karena perbuatan tersebut bertentangan dengan prinsip penghormatan terhadap manusia, karena manusia terhormat ketika hidup dan ketika dia telah mati. ${ }^{18}$

Yang dimaksud dalam keadaan darurat yang membolehkan dilakukannya pembongkaran kuburan dan memindahankan jenazahnya yaitu karena tujuan untuk kemaslahatan jenazah, misalkan kalau tanah pekuburan tersebut dikhawatirkan akan dilanda bencana banjir atau ada sesuatu yang mengancam keselamatan jenazah yang ada di dalam kuburan. Maka pada waktu itu boleh membongkar kuburan dan memindahkannya ke tempat lain yang lebih layak. ${ }^{19}$

Sebab selanjutnya dibolehkannya memindah jenazah yang telah dikuburkan adalah tanah yang digunakan untuk mengubur bukan hak dari jenazah tersebut. Menurut para ahli fiqih, bahwa di bolehkan memindahkan jenazah dari tanah yang tidak jelas statusnya kepada kuburan yang memang ditentukan. Dan diutamakan menguburkan seorang Muslim pada daerah kuburan yang lebih banyak orang shalehnya. ${ }^{20}$

Kemaslahatan masyarakat umum menjadi sebab selanjutnya dibolehkannya memindahkan jenazah yang telah dikuburkan, seperti akan di bangun masjid, sekolah, rumah sakit, dll di atas tanah kuburan tersebut. Hal ini termasuk pokok syariat yang menyebutkan bahwa menghilangkan mudharat dan menolaknya sedapat mungkin, menanggung mudharat yang lebih kecil dari menolak mudharat yang lebih besar, dan menghilangkan kemaslahatan yang lebih kecil untuk memperoleh kemaslahatan yang lebih besar.

\section{Kesimpulan}

Pemakaman Umum 21 merupakan pemakaman campur agama yang ada di Kota Metro. Hal ini menunjukkan betapa beragamnya warga Kota Metro dan betapa tolerannya mereka. Namun di satu sisi, hal ini dapat menyebabkan konflik jika mereka salah memahami konsep agama yang ada, terutama tentang pemakaman.

Di Pemakaman Umum 21 terdapat tiga agama yang berhak menggunakannya, yaitu agama Kristen Protestan dan Kristen Katolik, serta agama Islam. Untuk agama Kristen Protestan dan Kristen Katolik, pemakamannya diletakkan di satu blok yaitu di sebelah selatan pemakaman, sedangkan yang beragama Islam di letakkan di blok sebelah utara. Kedua blok

\footnotetext{
18 Yusuf Qardhawi, Fatwa-fatwa Kontemporer, (Jakarta: Gema Insani Press, 1995), h. 917

19 Said Abdullah Al Hamdani, Risalah Djanaiz, (Bandung: PT. Al Ma'arif, t.th), h. 123

${ }^{20}$ Husein Bahreisj, Himpunan Fatwa, (Surabaya: Al Ikhlas, 1987), h. 478
} 
tersebut dipisahkan dengan paving blok yang berfungsi untuk jalan pejiarah ukuran lebarnya sekitar 2 meter. Kedua blok yang ada di Pemakaman Umum 21 ini terletak dalam satu lingkaran pagar pembatas yang tingginya kira-kira 3 meter.

Dari kondisi yang telah dipaparkan mengenai pemakaman umum 21 dan dari beberapa hadis tentang jenazah dan pemakaman, maka dapat diketahui bahwa pemakaman umum 21 layak sebagai pemakaman umum. Namun ada beberapa hadis yang mengatakan bahwa pemakaman yang baik bagi seorang muslim adalah yang dekat dengan sesama muslim atau bahkan seseorang yang semasa hidupnya menguasai tentang ilmu agama atau bisa disebut Ustad, Kiyai, atau Ulama. Dari pemaparan teori yang ada pun ada beberapa kasus mengenai pemindahan jenazah yang telah disepakati oleh Majelis Ulama Indonesia dalam kasus Bung Tomo. Jadi, kalau memang keluarga berkehendak untuk memindahkan pemakaman yang sudah terlanjur ada itupun tidak menjadi permasalahan, selama sesuai aturan yang ada.

Untuk pemakaman 21, dahulu memang telah ada kesepakatan bersama mengenai peletakkan makam. Dengan keterbatasan lahan di Kota Metro sehingga terbentuklah pemakaman campuran ini. Hal ini seharusnya menjadi perhatian pemerintah daerah, terutama Dinas Tata Kota, untuk segera mengatur regulasi mengenai pemakaman di Kota Metro. Sebelum terjadinya konflik antar warga, semestinya pemerintah daerah harus lebih peka terhadap dampak ke depan yang akan ditimbulkan. Melihat betapa sensitifnya permasalahan SARA di Negara kita.

\section{DAFTAR PUSTAKA}

Abdul Majid Khon, 2013, Ulumul Hadis, Jakarta: Bumi Aksara

Abdullah bin Abdurrahman Alu Bassan, 2011, Syarah Hadits Pilihan Bukhari-Muslim, Bekasi: Darul Falah

Abdurrahman al-Jaziri, al-Fiqh 'alal Madzahibil Arba 'ah, Juz I, Beirut: Dar Al-Kuitub alAlawiyah, t.th

Al Albani, Muhmmad Nashiruddin, 2007, Shahih Sunan At-Tirmidzi 1, Jakarta: PUSTAKAAZZAM.

B. Ahmad Soebani. 2009. Metode Penelitian Hukum. Bandung: CV. Pustaka Setia

Bukhari Umar, 2012, Hadis Tarbawi (Pendidikan dalam perspektif hadis), Jakarta: Bumi Aksara

Husaini A. Majid Hasyim, 1993, Syarah Riyadhus Shalihin 2, Surabaya: Bina Ilmu 
Husein Bahreisj, 1987, Himpunan Fatwa, Surabaya: Al Ikhlas

Imam An-Nawawi, 1994, Terjemah Syarah Shahiih Muslim, Jak-Sel:Daarul Hadiits

Irawan Soehartono. 1999. Metode Penelitian Sosial Suatu Teknik Penelitian Bidang Kesejahteraan Sosial Lainnya. Bandung: Remaja Rosda Karya

K.H. Ma'ruf Amin, dkk. 2011. HIMPUNAN FATWA MAJELIS ULAMA INDONESIA SEJAK 1975, Jakarta: Erlangga

Lexy Moleong, 2000, Metodologi Penelitian Kualitatif., Remaja Rosdakarya

Mahjudin, Masailul Fiqhiyah, 1990, Berbagai Kasus yang Dihadapi Islam Masa Kini Jilid I, Jakarta: Kalam Mulia

Noeng Muhajir. 1989. Metode Penelitian Kuantitatif. Jakarta: Rake Sarasin

Nuruddin 'Itr, 2012, 'Ulumul Hadis, Bandung: Rosdakarya

Sahal Mahfudh, Ahkamul Fuqaha, 2004, Solusi Problematika Aktual Hukum Islam, Surabaya: LTN NU Jawa Timur

Said Abdullah Al Hamdani, Risalah Djanaiz, Bandung: PT. Al Ma'arif, t.th

Suharsimi Arikunto, 2004, Prosedur Penelitian: Pendekatan Praktek, Bumi Aksara:Jakarta

Sutrisno Hadi, 1990, Metodologi Research 3, Yogyakarta: Andi Offset

Syaikh Muhammad bin Shalih Al-Utsaimin, 2012, Syarah Hadits Arba'in, Jakarta Timur: Ummul Qura 